\title{
RATINGS OF INVESTMENT APPEAL OF REGIONS OF RUSSIA AS A TOOL OF ASSESSMENT OF REGION MANAGEMENT EFFICIENCY
}

\author{
Irina Bondarenko \\ Siberian Institute of management, Presidential Academy of National Economy and Public Administration, Russia
}

\section{SUMMARY}

One of a determinant of region management efficiency is sustainable economic development that is based on active attraction of investments and business development in the region. Thus, appeal of the region for investments can used as an indicator of authorities' efficiency in the region. The article considers possibility of application of independent ratings of regions for an assessment of region management efficiency.

Keywords: investment appeal, region management efficiency.

\section{INTRODUCTION}

In the modern conditions of economy globalization, and of sharp competition among the countries, regions and cities for resources (financial, labor, intellectual and so forth), the special level of efficiency of the territorial management becomes highly significant. Issues of quality of region management in subjects of the Russian Federation with regard to supporting of the balanced social and economic development, and detection of points of growth of economy in country scales, are especially relevant and important nowadays.

In a broad sense, quality of region management can be evaluated taking into account the complex index of competitiveness of the region, i.e. ability of its economy to make more riches in comparison with other territories and to create conditions for higher level and quality of life. Thus, competitiveness of the region, and, therefore, efficiency of the region management can be shown by means of showing figures of quality of life of the population and the level of attractiveness of the region for organizing and conducting of business and investment activity.

The most recognized valuation method of investment appeal of the territories is ratings, because this tool allows not only estimating an object condition, but also comparing advantages and shortcomings of investment climate of certain territories. Now the world leading analytical groups conduct researches and ratings of competitiveness, business attractiveness of the countries, regions and cities, whose results make the basis of the policy of stimulation of economic growth, development of business and increase of competitiveness of the region. Besides, similar ratings of the territories are used as the tool for the analysis of problem points in economic policy and imperfections of management, and also for development of strategy for achievement of sustainable social and economic development of the territory. Global competitiveness index, calculated by a technique of the World economic forum, World Competitiveness Ranking, made by the International Institute of Administrative Development (IMD) in Lausanne, and the Rating of Doing Business, made by analytical group of the World Bank and the International Finance Corporation, appear to be the most complex world researches and the associated ratings of the countries (Knyazeva and Bondarenko, 2014).

\section{RATINGS OF INVESTMENT APPEAL: METHODOLOGY, INDICATORS, RESULTS}

Now in Russia the large-scale operation on formation of system of assessment of the status of enterprise climate and investment appeal of regions of the country, connected with the need for creation of incentives and conditions 
for development of market institutes and the competitive environment on the one hand, and improvement of quality of regional government and efficiency of activities of authorities on the other hand, is carried out. Several policy measures, aimed at creation of the favorable environment for development of business processes, strengthening of investment activity in regions for the purpose of having radical increase in efficiency of national economy, are being developed within the concept of Management by objectives. Ratings of investment appeal of regions can serve as the tool for assessment of efficiency of implementation of the specified policy measures. However, results of rating of regions first of all depend on indexes, selected for assessment, and also on the technique of rating formation, being the basis of it.

We will consider three ratings of investment appeal of regions of Russia, made by different analytical groups:

1. Rating of investment appeal of regions of Russia according to the Expert Rating Agency;

2. Rating of investment appeal of regions of Russia according to National Rating Agency;
3. The national rating of investment climate in territorial subjects of the Russian Federation made by Agency of Strategic Initiatives.

All three ratings are aimed at comparing of advantages and shortcomings of each subject of Russia with regard to implementation of investment activities, and also at giving ideas for authorities for improving of investment climate in the region. However, ratings significantly differ by their compilation techniques.

The fundamental issue of compilation of rating of investment appeal of regions, according to Expert RA, is the fact that each region has two characteristics from the point of view of a potential investor: investment potential of the territory and its investment risk. The investment potential represents the quantitative indices, influencing volumes of potential investments into the region and includes 9 private potentials. Investment risk in Expert RA technique represents the qualitative characteristics, which depend on the political, social, economic, financial, ecological and criminal situation. Its value shows probability of investment losses and incomes.

The contribution of each component to the cumulative potential or to a certain risk var-

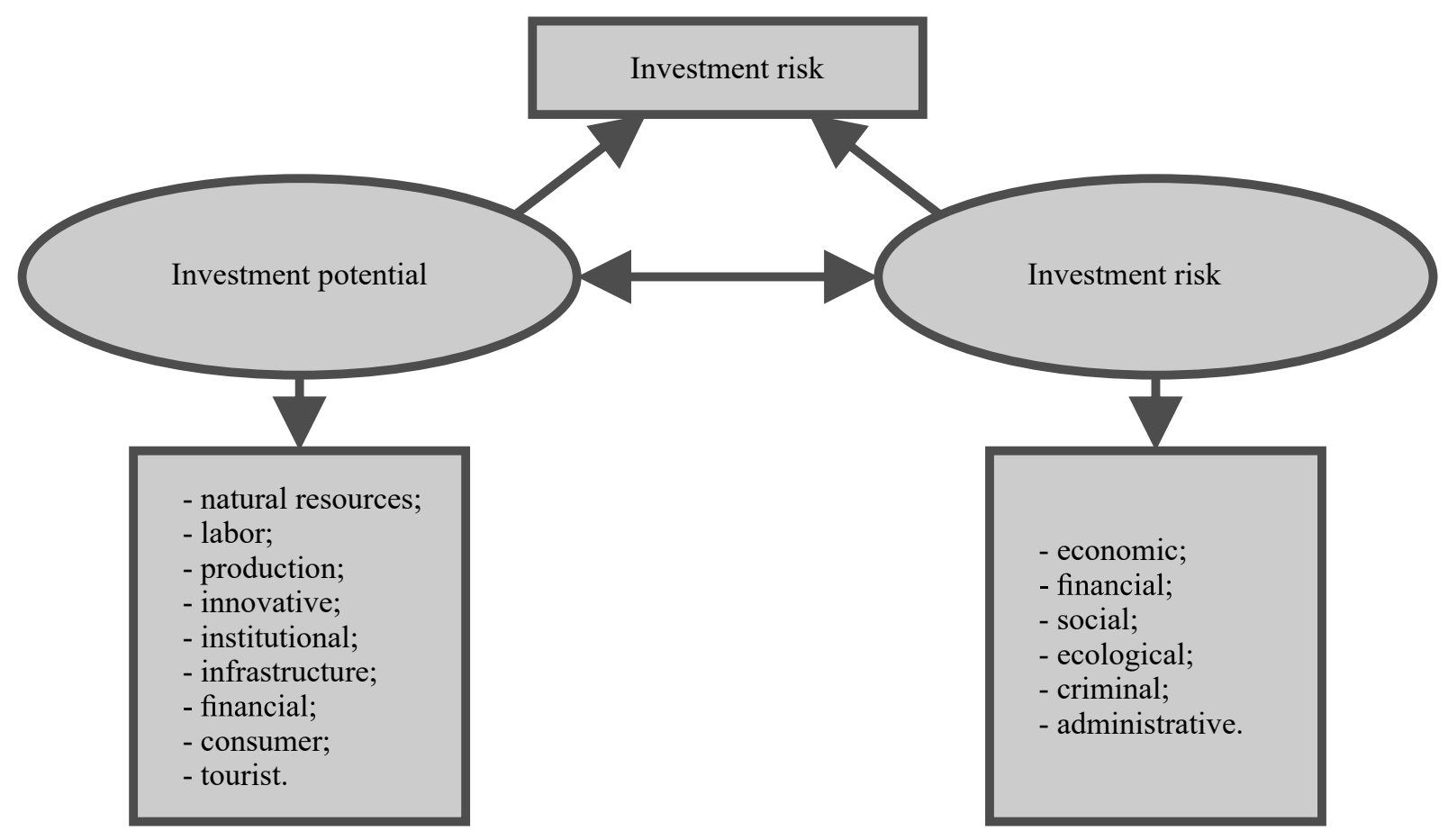

Scheme 1. Structure of investment appeal according to RA Expert 
ies a lot. The assessment of coefficient of the relative significance is carried out by annual inquiry, carried out among experts from the Russian and foreign investment and consulting companies and enterprises. Regions have been grouped into 12 rating categories by the ratio of cumulative potential to the integral risk. The main information sources for compilation of the rating are the data of the Federal State statistics service, Ministry of Finance of the Russian Federation, Ministry of Economic Development and Trade of the Russian Federation, the Central Bank of the Russian Federation, the Ministry of Taxation and Tax Collection of the Russian Federation, Ministry of Natural Resources of the Russian Federation, Centre of Economic Environment at the Government of the Russian Federation, the legal database "Consultant Plus-Regiony", and the database of Expert rating agency (Expert Rating Agency, 2014).

The similar technique of compilation of the rating of investment appeal is used by National Rating Agency. Regions are also grouped in accordance with their level of investment appeal (9 groups in total), however, only the factors of investment appeal are used as the initial indexes (without different risks of investment losses or profits). In total, seven such factors are selected:

1. Natural resource endowment and quality of environment in the region: existence of main types of natural resources in the region (including fuel and energy), level of environmental pollution, possibility of cleaning of sinks and processing of production wastes.

2. work forces of the region: the main characteristics of work forces of the region, including the number of the economically active population, employment and unemployment rates, score of the qualified labor offer, and also labor productivity.

3. regional infrastructure: level of development and accessibility of both "hard", and "soft" infrastructure. The concept of "hard" infrastructure includes transport, energetic, telecommunication, and hous- ing infrastructure. The "soft" infrastructure includes some components, among which the financial infrastructure has the greatest value from the point of view of investment appeal.

4. domestic market of the region (regional demand potential): the level of development of domestic market of the region (including retail trade and paid services sectors scales), the located income and purchasing capacity of the region population.

5. production potential of regional economy: cumulative results and features of economic activity of the enterprises which are already working in the region (volume and dynamics of production, the assets volume, their quality and efficiency of their use).

6. institutional environment and socio-political stability: an expert assessment of efficiency of the regional legislation, regulating interaction of the authorities and investors, an expert assessment of favorability of the regional tax law (existence of tax privileges and possibility of their receiving), level of social and criminal tension in the region.

7. financial stability of the regional budget and enterprises: the status of public finances in the region (the amount of tax revenues, balance of the budget, regional public debt), and also an assessment of a financial position of the enterprises of the region (profitability (unprofitability) of firms, the payables/ receivables balance status of the organizations, existence of investment resources) (National Rating Agency, 2013).

For determination of the relative significance of individual factors in the total assessment of investment appeal, the survey is conducted by experts - representatives of investment and scientific community (experts in the field of the direct and portfolio investments, having experience with investment projects in the Russian regions).

Essentially different approach to the assessment of investment climate in regions 
of Russia is used in making rating by the Agency of Strategic Initiatives (ASI). The technique of compilation of the investment climate rating is in many respects similar to the technique of business conditions assessment, one of whose fundamental principles consists in the fact, that for guiding of economic activity transparent qualitative rules are required, which can be used by all economic subjects. Therefore, the authors of the ASI rating technique use indexes of business institutional conditions in the region as the key criteria:

1. Regulatory environment indexes (efficiency of enterprises registration procedures, granting construction licenses, registration of the property rights, granting other permissions and licenses, connection of the electric power);

2. Institutes for business (efficiency of the institutes, providing security of business, business load, connected with checks and inspections, the level of transparency of business, overall performance of organizational mech- anisms of business support, quality of information support of investors and business);

3. Accessibility of resources and quality of infrastructure for business (quality and accessibility of infrastructure, territorial planning quality, land resources accessibility, quality and accessibility of financial support, and of work forces);

4. Support of small and medium business (level of development of small business in the territorial subject of the Russian Federation, quality of organizational, infrastructure and information support of small business, efficiency of non-financial and financial support of small business) (Agency of Strategic Initiatives, 2014).

Despite a general goal of assessment of the considered techniques, the created ratings of regions of Russia, following the results of 2014 , specify the strong dependence of the results of an assessment on the selected indexes and on the regions ranging technique. Results of Russian regions ratings in accordance with the considered techniques are given in table 1 .

Table 1.

Ranks of regions of Russia with regard to their investment appeal by different assessment techniques

\begin{tabular}{lccc}
\hline $\begin{array}{c}\text { Subject of the } \\
\text { Russian Federation }\end{array}$ & RA Expert & $\begin{array}{c}\text { National Ratings } \\
\text { Agency }\end{array}$ & $\begin{array}{c}\text { Agency of Strategic } \\
\text { Initiatives }\end{array}$ \\
\hline Altai region & 46 & 55 & 35 \\
\hline Altai Republic & 63 & 64 & 64 \\
\hline Amur region & 61 & 19 & 65 \\
\hline Arhangelsk region & 30 & 27 & 48 \\
\hline Astrakhan region & 34 & 40 & 34 \\
\hline Belgorod region & 5 & 3 & 32 \\
\hline Bryansk region & 21 & 56 & 14 \\
\hline Chechen Republic & 66 & 67 & 25 \\
\hline Chelyabinsk region & 16 & 38 & 86 \\
\hline Chuvash Republic & 38 & 54 & 33 \\
\hline Irkutsk region & 18 & 29 & 60 \\
\hline Ivanovo region & 23 & 59 & 2 \\
\hline Kaliningrad region & 32 & 11 & \\
\hline Kaluga region & 24 & 12 & \\
\hline
\end{tabular}

Note: Table 1 continued on next page 


\begin{tabular}{|c|c|c|c|}
\hline Kamchatka Krai & 64 & 21 & 29 \\
\hline Kemerovo region & 19 & 43 & 18 \\
\hline Khabarovsk region & 50 & 18 & 56 \\
\hline Kirov region & 39 & 60 & 22 \\
\hline Komi Republic & 29 & 16 & 38 \\
\hline Kostroma region & 52 & 57 & 6 \\
\hline Krasnodar region & 4 & 4 & 7 \\
\hline Krasnoyarsk region & 17 & 30 & 53 \\
\hline Kurgan region & 59 & 61 & 59 \\
\hline Kursk region & 9 & 22 & 16 \\
\hline Leningrad region & 13 & 5 & 17 \\
\hline Lipetsk region & 10 & 23 & 31 \\
\hline Magadan Region & 65 & 13 & 58 \\
\hline Mari El Republic & 57 & 62 & 26 \\
\hline Moscow & 2 & 1 & 11 \\
\hline Moscow region & 1 & 6 & 19 \\
\hline Murmansk region & 33 & 31 & 30 \\
\hline Nizhny Novgorod Region & 14 & 14 & 41 \\
\hline Novgorod region & 54 & 24 & 57 \\
\hline Novosibirsk region & 20 & 32 & 49 \\
\hline Omsk region & 47 & 33 & 54 \\
\hline Orenburg region & 40 & 34 & 46 \\
\hline Oryol Region & 53 & 44 & 24 \\
\hline Penza region & 41 & 45 & 10 \\
\hline Pskov region & 55 & 58 & 51 \\
\hline Republic of Adygea & 56 & 46 & 50 \\
\hline Republic of Bashkortostan & 6 & 15 & 36 \\
\hline Republic of Buryatia & 45 & 47 & 44 \\
\hline Republic of Khakassia & 60 & 48 & 42 \\
\hline Republic of Mordovia & 58 & 63 & 21 \\
\hline Republic of North Ossetia - Alania & 62 & 65 & 63 \\
\hline Republic of Sakha (Yakutia) & 49 & 25 & 37 \\
\hline Republic of Tatarstan & 7 & 7 & 1 \\
\hline Ryazan Oblast & 25 & 49 & 62 \\
\hline Saint Petersburg & 3 & 2 & 23 \\
\hline Sakhalin region & 51 & 9 & 47 \\
\hline Samara Region & 15 & 8 & 40 \\
\hline Saratov region & 42 & 35 & 43 \\
\hline Smolensk region & 26 & 50 & 52 \\
\hline Stavropol region & 36 & 51 & 45 \\
\hline Tambov Region & 11 & 36 & 4 \\
\hline Tomsk region & 48 & 17 & 20 \\
\hline Tula region & 12 & 26 & 9 \\
\hline Tver region & 27 & 52 & 61 \\
\hline Tyumen region & 44 & 10 & 13 \\
\hline
\end{tabular}

Note: Table 1 continued on next page 


\begin{tabular}{lccc}
\hline Tyva Republic & 67 & 66 & 67 \\
\hline Udmurt republic & 37 & 53 & 39 \\
\hline Ulyanovsk region & 43 & 37 & 5 \\
\hline Vladimir region & 22 & 28 & 55 \\
\hline Volgograd region & 35 & 41 & 28 \\
\hline Vologda Region & 31 & 42 & 12 \\
\hline Voronezh region & 8 & 20 & 27 \\
\hline Yaroslavl region & 28 & 39 & \\
\hline
\end{tabular}

Source: Expert Rating Agency, 2014; National Rating Agency, 2014; Agency of Strategic Initiatives, 2014

The data, provided in the table, shows inconsistency of results of investment climate assessment in regions of Russia. For assessing the level of coherence of rating places, we calculated Spearmen's coefficient of rank order correlation, which showed existence of noticeable correlation between the ratings of investment appeal of regions, calculated by RA Expert and the National Rating Agency techniques, and, at the same time, it showed total absence of parallelism in estimates of investment climate by Agency of Strategic Initiatives and Expert RA, and between Agency of Strategic Initiatives and National Rating Agency.

Table 2

Spearman rank order correlations

\begin{tabular}{lccc}
\hline & RA Expert & National Ratings Agency & Agency of Strategic Initiatives \\
\hline RA Expert & - & 0.5304 & 0,4197 \\
\hline National Ratings Agency & 0.5304 & - & 0,2353 \\
\hline Agency of Strategic Initiatives & 0,4197 & 0,2353 & - \\
\hline
\end{tabular}

Similar discrepancies can be caused by the fact that when assessing the level of attractiveness of regions for investors, rating agencies focus on factors of the territory competitiveness from the point of view of profitability of investment contributions (high level of correlation between a rank of the region and the volume of investment into it by results 2014 proves that) while the rating of Agency of Strategic Initiatives considers regions from the point of view of actions of the authorities, aimed at better provision of the state services to business and creating favorable conditions for conducting of business activity.

\section{CONCLUSION}

Thus, the rating of regions for the level of investment appeal can serve as one of the segments of system of assessment of regional management efficiency, by way of assessing the quality of the provided state services, and of the analysis of fulfillment of one of the main tasks of region management - attraction of additional resources to the region and increase of its competitiveness.

However, while ranks of investment appeal of Russian regions are included in a system of an assessment of government efficiency, it is necessary to consider all methodology of rating formation, also indicators, which form the basis. As the aim of rating defines a set of the indicators and, respectively, the results, authorities need to understand accurately, what aspects of their activity are exposed to an assessment.

\section{REFERENCES}

Agency of Strategic Initiatives. (2014). The national rating of investment climate in territorial subjects of the Russian Federation. Retrieved April 3, 2016 from site http://investinregions.ru/rating/. 
Expert Rating Agency. (2014). Rating of investment appeal of Russian regions 2014. Retrieved April 2, 2016 from http://www.raexpert.ru/project/ regcongress/2014/ranking/.

Hauner, D and Kyobe, A. (2008).

Determinants of Government Efficiency. Retrived April 2, 2016 from https:// www.imf.org/external/pubs/ft/wp/2008/ wp08228.pdf.

Knyazeva, I. and Bondarenko, I. (2014) . System-based characteristics of ratings containing assessment of entrepreneurial and investing climate: ranking of Russia. Management issues, 4 (10), p. 82-97.

Knyazeva, I., Chirikhin S. and Bondarenko I. (2014). Empirical method of Assessment of the Competitive Environment in the Russian Federation: Characteristics and Methodological Review. ETAP: economic Theory, Analysis, and Practice, 3, p. 53-71.
National Rating Agency. (2014). Rating of investment appeal of regions of Russia-2014. Retrieved March 30, 2016 from http://www.ra-national.ru/ru/ taxonomy/term/90.

The World Bank. (2016). Doing Business 2016-Measuring regulatory quality and efficiency. Retrieved March 30, 2016 from site http://russian.doingbusiness. org/ /media/GIAWB/Doing\%20 Business/Documents/Annual-Reports/ English/DB16-Full-Report.pdf.

World economic forum. (2015). The Global Competitiveness Report 2015-2016. Retrieved March 30, 2016 from https:// www.weforum.org/reports/globalcompetitiveness-report-2015. 
